\title{
Cardiovascular safety of sitagliptin in patients with type 2 diabetes mellitus: a pooled analysis
}

\author{
Samuel S Engel", Gregory T Golm, Deborah Shapiro, Michael J Davies, Keith D Kaufman and Barry J Goldstein
}

\begin{abstract}
Objective: To compare the incidence of cardiovascular events and mortality in patients with type 2 diabetes mellitus treated with sitagliptin or non-sitagliptin comparators.

Methods: A post hoc assessment of cardiovascular safety in 14,611 patients was performed by pooling data from 25 double-blind studies, which randomised patients at baseline to sitagliptin $100 \mathrm{mg} /$ day or a non-sitagliptin comparator (i.e., non-exposed). Included studies were limited to those at least 12 weeks in duration (range: 12 to 104 weeks). Patient-level data were used in this analysis of major adverse cardiovascular events (MACE) including ischaemic events and cardiovascular deaths. Analyses were performed in three cohorts: the entire 25-study cohort, the cohort from placebo-controlled portions of studies $(n=19)$, and the cohort from studies comparing sitagliptin to a sulphonylurea $(n=3)$.
\end{abstract}

Results: In the entire cohort analysis, 78 patients had at least 1 reported MACE-related event, with 40 in the sitagliptin group and 38 in the non-exposed group. The exposure-adjusted incidence rate was 0.65 per 100 patient-years in the sitagliptin group and 0.74 in the non-exposed group (incidence rate ratio $=0.83[95 \%$ confidence interval (Cl): $0.53,1.30]$ ). In the analysis comparing sitagliptin to placebo, the exposure-adjusted incidence rate was 0.80 per 100-patient-years with sitagliptin and 0.76 with placebo (incidence rate ratio $=1.01$ [95\% Cl: $0.55,1.86]$ ). In the analysis comparing sitagliptin to sulphonylurea, the exposure-adjusted incidence rate was 0.00 per 100 patient-years with sitagliptin and 0.86 with sulphonylurea (incidence rate ratio $=0.00$ [95\% Cl: 0.00, 0.31]).

Conclusion: A pooled analysis of 25 randomised clinical trials does not indicate that treatment with sitagliptin increases cardiovascular risk in patients with type 2 diabetes mellitus. In a subanalysis, a higher rate of cardiovascular-related events was associated with sulphonylurea relative to sitagliptin.

\section{Introduction}

Type 2 diabetes mellitus is associated with an increased risk of cardiovascular disease and mortality [1,2]. Cardiovascular events account for approximately $70 \%$ of deaths in older patients with type 2 diabetes mellitus [3]. Furthermore, short- and long-term survival following a myocardial infarction is lower in patients with type 2 diabetes mellitus compared to those without [4-8]. In a prospective observational study, the risk of a subsequent myocardial infarction in patients with pre-existing diabetes was found to be comparable to patients with pre-existing coronary disease [9]. These and other data have supported the concept that type 2 diabetes mellitus is considered a coronary heart disease

* Correspondence: samuel_engel@merck.com

Merck Sharp \& Dohme Corp, Whitehouse Station, NJ, USA risk equivalent; treatment guidelines for lipid management for patients with type 2 diabetes parallel those for patients with prior coronary events [10]. Thus, prevention of cardiovascular disease is a major clinical challenge in treating patients with type 2 diabetes mellitus.

The potential role of antihyperglycaemic medications in the development and/or progression of cardiovascular disease has received increasing attention, related in large part to the observation that rosiglitazone was associated with an increased incidence of cardiovascular events [11-13]. As a reflection of the heightened concern regarding the intrinsic effects of antihyperglycaemic agents on cardiovascular safety, in 2008, the FDA instituted requirements for the assessment of cardiovascular safety as a key component of the clinical development programs for new antihyperglycaemic agents [14].

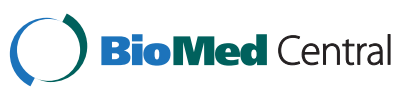


DPP-4 inhibitors are a newer class of antihyperglycaemic therapy and improve glycaemic control by inhibiting the inactivation of the incretin hormones, glucagon-like peptide-1 (GLP-1) and glucose-dependent insulinotropic polypeptide [15]. Sitagliptin, the first agent approved in this class of antihyperglycaemic agents, was introduced for clinical use in 2006. To date, DPP-4 inhibitors (sitagliptin, saxagliptin, vildagliptin, linagliptin, and alogliptin) have not been shown to be associated with an increased risk of cardiovascular events [16-20]. In view of the increased focus on the effects of antihyperglycaemic agents on cardiovascular outcomes, the present analysis expanded upon a previous cardiovascular assessment of sitagliptin [16] by including results from recently completed sitagliptin trials.

\section{Methods}

The present post hoc analysis used a pooled population $(\mathrm{N}=14,611)$ drawn from all 25 multicenter, U.S. or multinational, double-blind, parallel-group studies conducted by Merck \& Co., Inc., in which patients were randomised to receive sitagliptin $100 \mathrm{mg} /$ day $(\mathrm{n}=7,726)$ or a comparator $(n=6,885)$ for at least 12 weeks and up to 2 years (the duration of the longest studies) and for which results were available as of December 1, 2011 (complete study listing in Appendix I, Table 2). Each protocol was reviewed and approved by appropriate ethical review committees and authorities for each clinical site. All patients were to have provided written informed consent. The studies evaluated sitagliptin as monotherapy, initial combination therapy with either metformin or pioglitazone, or add-on combination therapy with other antihyperglycaemic agents including metformin, pioglitazone, a sulphonylurea (with and without metformin), insulin (with and without metformin), or metformin + rosiglitazone or pioglitazone. Patients not receiving sitagliptin (i.e., the non-exposed group) received placebo, metformin, pioglitazone, a sulphonylurea (with and without metformin), insulin (with and without metformin), or metformin + rosiglitazone or pioglitazone. From each contributing study, the pooling was conducted by including those portions that had parallel treatment groups with concurrent exposures to sitagliptin $100 \mathrm{mg} /$ day (primarily administered as $100 \mathrm{mg}$ once daily) or other treatments (either placebo or active comparator). Studies conducted only in Japan were excluded from all analyses; a lower starting dose of sitagliptin has been separately developed in Japan. The pooling excluded studies conducted in patients with moderate to severe renal insufficiency, because these patients received sitagliptin at doses less than $100 \mathrm{mg} /$ day.

In each study, investigators were to report adverse events (serious and non-serious) that occurred during the conduct of the study, as well as serious adverse events occurring within 14 days following the last dose of blinded study drug. The present analysis used patientlevel data from each study to assess the incidence rates of cardiovascular-related adverse events that occurred following initiation of double-blind study drug. Many studies in this analysis included open-label glycaemic rescue therapy, which was to have been initiated based upon progressively stricter, protocol-specified hyperglycaemia criteria. When initiated, glycaemic rescue therapy was added to the ongoing, blinded study medication to which patients had been randomised. The analysis in this pooled population includes all post-randomisation events reported to have occurred during a given study, including those events with onset after the initiation of glycaemic rescue therapy.

The primary outcome was major adverse cardiovascular events (MACE), which comprised ischaemic events and cardiovascular deaths (see Appendix II, Tables 3 and 4, for the definition of MACE used in the analysis). Analyses were performed in three cohorts: the entire 25-study cohort (sitagliptin vs. non-exposed), the cohort from placebo-controlled portions of studies (sitagliptin vs. placebo), and the cohort from studies comparing sitagliptin to a sulphonylurea (sitagliptin vs. sulphonylurea). The sitagliptin vs. placebo analysis was performed to eliminate any potential confounding effects from the various active comparators. The data were pooled from the placebocontrolled portions of 19 double-blind studies, which randomised patients at baseline to sitagliptin $100 \mathrm{mg} /$ day $(\mathrm{n}=$ $5,236)$ or placebo $(\mathrm{n}=4,548)$ for up to 1 year (Appendix I, Table 2). Since sulphonylureas have been associated with an increased risk for cardiovascular events relative to metformin in some, but not all, observational studies [21-26], the sitagliptin vs. sulphonylurea analysis was performed by pooling the three double-blind studies (P010, P024, P803), which randomised patients at baseline to sitagliptin 100 $\mathrm{mg} /$ day $(\mathrm{n}=1,226)$ or a sulphonylurea $(\mathrm{n}=1,225)$ for up to 2 years [27-30]. Two sensitivity analyses were performed to assess the robustness of the results from the primary comparisons of sitagliptin vs. non-exposed and sitagliptin vs. sulphonylurea. These analyses included all trials or portions of trials in which sitagliptin $100 \mathrm{mg}$ or corresponding control were given in a blinded fashion, even if those treatments reflected a switch from the treatment given at randomization. The first sensitivity analysis extended the primary analysis of sitagliptin vs. nonexposed by adding all patients from two phase 2 doseranging studies (P010, P014) who initially received placebo or doses of sitagliptin less than $100 \mathrm{mg}$, but were subsequently switched to sitagliptin $100 \mathrm{mg}$. Only those events that occurred after the switch to sitagliptin $100 \mathrm{mg}$ were counted in the analysis. The second sensitivity analysis extended the primary analysis of sitagliptin vs. sulphonylurea by adding the same patients from P010 who were added to the first sensitivity analysis, as well as all patients 
from a 104-week phase 3 study (P020) in which patients were randomised to receive sitagliptin or placebo for the first 24 weeks, with the placebo group switching to a sulphonylurea after Week 24. Only the Week 24 to Week 104 data from P020 were included in the second sensitivity analysis.

\section{Statistical Analyses}

To account for potential differences between groups in duration of exposure to treatment, MACE was analyzed in terms of exposure-adjusted incidence rates (i.e., the number of patients with $\geq 1$ event divided by the total patient-years of exposure). For patients who had an event, exposure was calculated as the time from the first dose of study medication at randomisation to the time that the first post-randomisation event occurred. For patients without an event, exposure was calculated as the time from the first dose to 14 days after the last dose. Exposure-adjusted incidence rate ratios (sitagliptin relative to comparator) and the associated 95\% confidence intervals (CI) were calculated using an exact method for Poisson processes [31], stratified by study. Studies in which no events occurred were excluded from analyses using this approach. A sensitivity analysis was conducted using the Mantel-Haenszel method [32], which included studies with no events by use of a continuity correction factor. An additional sensitivity analysis was conducted using Cox regression. All analyses were performed using SAS Version 9.1.

\section{Results}

At baseline, patients in the entire 25-study cohort (55\% male) had an average age of 54 years (range: 19 to 91 years; $17 \% \geq 65$ years), a median duration of diabetes of 3.5 years, and a mean $\mathrm{HbA}_{1 \mathrm{c}}$ of $8.4 \%$ (Table 1). The cohort was $61 \%$ Caucasian, $18 \%$ Asian, and 6\% Black. At baseline, $10 \%$ of patients had a history of cardiovascular disease, and $81 \%$ had additional cardiovascular risk factors besides type 2 diabetes mellitus and cardiovascular disease, including hypertension (53\%), history of dyslipidaemia/hypercholesterolaemia (49\%), and history of smoking (39\%). There were no meaningful differences between groups in these baseline characteristics.

The mean exposure to study drug was greater in the sitagliptin group relative to the non-exposed group: 284 dosing days (range: 1 to 791) relative to 264 dosing days (range: 1 to 801), respectively. In the sitagliptin group, $2,457(32 \%)$ patients were treated for at least 1 year, with 584 of these patients treated for 2 years; the corresponding numbers of patients were $1,775(26 \%)$ and 470 in the non-exposed group. In this pooled analysis of studies 12 weeks to 2 years in duration, the proportions of patients discontinuing treatment were $27.2 \%$ in the sitagliptin group and $28.8 \%$ in the non-exposed group.
Table 1 Baseline characteristics of randomised patients

\begin{tabular}{|c|c|c|}
\hline Characteristic & $\begin{array}{l}\text { Sitagliptin } \\
(\mathrm{n}=7,726)\end{array}$ & $\begin{array}{c}\text { Non-exposed } \\
(n=6,885)\end{array}$ \\
\hline Age, years & $54.0 \pm 10.3$ & $54.4 \pm 10.5$ \\
\hline Age $\geq 65$ years, $n(\%)$ & $1,261(16)$ & $1,185(17)$ \\
\hline \multicolumn{3}{|l|}{ Gender, n (\%) } \\
\hline Male & $4,196(54)$ & $3,788(55)$ \\
\hline Female & $3,530(46)$ & $3,097(45)$ \\
\hline \multicolumn{3}{|l|}{ Race, n (\%) } \\
\hline Caucasian & $4,674(60)$ & $4,227(61)$ \\
\hline Black & $427(6)$ & $384(6)$ \\
\hline Asian & $1,436(19)$ & $1,227(18)$ \\
\hline Multiracial & $462(6)$ & $427(6)$ \\
\hline Other or unknown & $727(9)$ & $620(9)$ \\
\hline Ethnicity, Hispanic or Latino, n (\%) & $1,917(25)$ & $1,690(25)$ \\
\hline Body weight, kg & $85.0 \pm 19.6$ & $85.8 \pm 20.1$ \\
\hline Body mass index, $\mathrm{kg} / \mathrm{m}^{2}$ & $30.5 \pm 5.7$ & $30.7 \pm 5.8$ \\
\hline Duration of T2DM, years* & 3.0 & 4.0 \\
\hline \multicolumn{3}{|l|}{ Distribution of duration of T2DM, n (\%) ${ }^{\dagger}$} \\
\hline$<5$ years & $4,535(59)$ & $4,002(58)$ \\
\hline$\geq 5$ and $<10$ years & $1,864(24)$ & $1,690(25)$ \\
\hline$\geq 10$ years & $1,316(17)$ & $1,188(17)$ \\
\hline $\mathrm{HbA}_{1 c}, \%$ & $8.4 \pm 1.3$ & $8.4 \pm 1.3$ \\
\hline \multicolumn{3}{|l|}{$\mathrm{HbA}_{1 c}$ distribution at baseline, $\mathrm{n}(\%)$} \\
\hline $\mathrm{HbA}_{1 \mathrm{c}}<8 \%$ & $3,190(41)$ & $2,924(42)$ \\
\hline $\mathrm{HbA}_{1 \mathrm{c}} \geq 8$ to $<9 \%$ & $2,258(29)$ & 1,931 (28) \\
\hline $\mathrm{HbA}_{1 \mathrm{c}} \geq 9 \%$ & 2,264 (29) & $2,016(29)$ \\
\hline History of CVD, n (\%) & $792(10)$ & $691(10)$ \\
\hline $\begin{array}{l}\text { Proportion of patients with known CV } \\
\text { risk factors other than T2DM and history } \\
\text { of CVD, } \mathrm{n}(\%)^{\dagger+}\end{array}$ & $5,827(81)$ & $5,266(82)$ \\
\hline History of dyslipidaemia, n (\%) & $3,857(50)$ & $3,350(49)$ \\
\hline History of hypertension, n (\%) & $4,110(53)$ & $3,666(53)$ \\
\hline History of smoking, $\mathrm{n}(\%)^{\dagger+}$ & 2,712 (38) & 2,539 (39) \\
\hline \multicolumn{3}{|c|}{$\begin{array}{l}\text { T2DM = type } 2 \text { diabetes mellitus, CV=cardiovascular, CVD = cardiovascular } \\
\text { disease. } \\
\text { Data are expressed as mean ( } \pm \text { standard deviation) or frequency ( }[\%] \text { ), unless } \\
\text { otherwise indicated. } \\
{ }^{*} \text { Median. } \\
{ }^{+} \text {Number of patients with unknown duration of diabetes was } 11 \text { in the } \\
\text { sitagliptin group and } 5 \text { in the non-exposed group. } \\
++ \text { Denominator is } 7,177 \text { and } 6,451 \text {, respectively because history of smoking } \\
\text { was not routinely collected in all sitagliptin studies. }\end{array}$} \\
\hline
\end{tabular}

\section{MACE Analyses}

\section{Entire 25-study Cohort}

In the 25-study cohort, events occurred in 21 of the studies. After excluding the 4 studies with no events (P019, P061, P128, and P801; Appendix I, Table 2), 13,462 of the 14,611 patients contributed to the primary analysis using the exact method, and the cumulative patient exposure was 6,157 patient-years for the sitagliptin 
group and 5,114 patient-years for the non-exposed group. A total of 78 patients had at least one reported MACE-related event, with 40 in the sitagliptin group and 38 in the non-exposed group. The exposureadjusted incidence rates per 100 patient-years were 0.65 in the sitagliptin group and 0.74 in the non-exposed group (adjusted incidence rate ratio $=0.83$ [95\% CI: $0.53,1.30]$ ) (Figure 1). For cardiovascular-related deaths, there were 12 in the sitagliptin group compared to 10 in the non-exposed group. The exposure-adjusted incidence rate for cardiovascular-related death was 0.25 per 100-patient-years for both the sitagliptin and nonexposed group (adjusted incidence rate ratio $=0.95[95 \%$ CI: $0.40,2.30])$. In the sensitivity analysis that included all blinded exposure to sitagliptin $100 \mathrm{mg}(\mathrm{n}=8,128$ sitagliptin, $\mathrm{n}=6,885$ non-exposed), the cumulative patient exposure excluding studies with no events was 6,596 patient-years for the sitagliptin group and 5,114 patient-years for the non-exposed group. A total of 86 patients had at least one MACE-related event reported, with 48 in the sitagliptin group and 38 in the nonexposed group. The exposure-adjusted incidence rate was 0.73 per 100 -patient-years in the sitagliptin group and 0.74 in the non-exposed group (adjusted incidence rate ratio $=0.87$ [95\% CI: $0.56,1.35]$ ).

\section{Sitagliptin vs. Placebo}

Baseline characteristics were similar between treatment arms (data not shown). The cumulative patient exposure was approximately 3,335 patient-years with sitagliptin and 2,922 patient-years with placebo. In this 19-study subanalysis, 24 patients in the sitagliptin group compared to 20 in the placebo group had at least one MACE-related event. The exposure-adjusted incidence rate was 0.80 per 100 -patient-years with sitagliptin and 0.76 with placebo (adjusted incidence rate ratio $=1.01$ [95\% CI: $0.55,1.86])$. There were 6 cardiovascularrelated deaths in the sitagliptin group compared to 3 in the placebo group. The exposure-adjusted incidence rate for cardiovascular-related death was 0.28 per 100patient-years with sitagliptin and 0.15 with placebo (incidence rate ratio $=1.79$ [95\% CI: 0.44, 8.79]).

\section{Sitagliptin vs. Sulphonylurea}

Baseline characteristics were similar between treatment arms (data not shown). The cumulative patient exposure was approximately 1,269 patient-years in the sitagliptin group and 1,274 patient-years in the sulphonylurea group. In this three-study subanalysis, events were reported in all 3 studies. No patients in the sitagliptin group compared to 11 in the sulphonylurea group experienced a MACE-

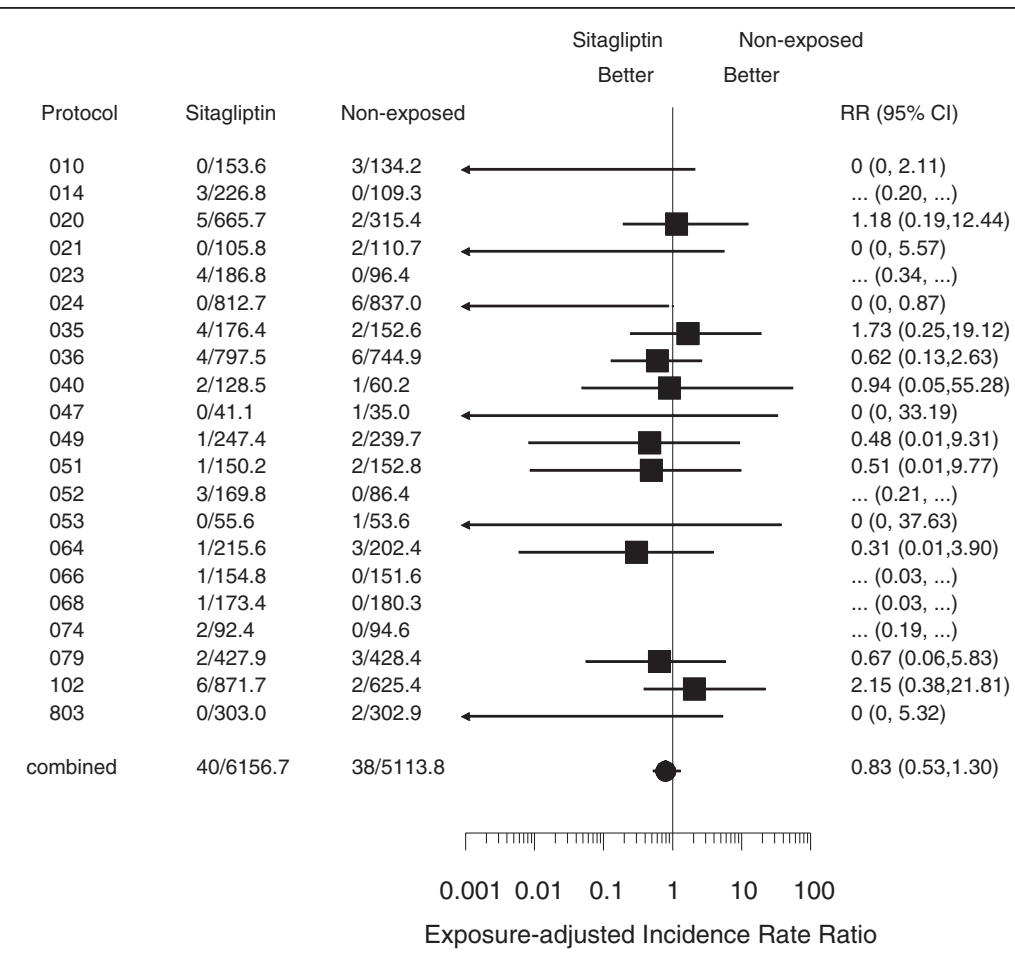

Figure 1 Forest plot of custom MACE (Exposure-adjusted incidence rate ratios). The second and third columns display the number of patients with $\geq 1$ event/patient-years follow-up time. The estimates of rate ratio and 95\% confidence intervals (Cl) are calculated using exact method stratified by study. Studies with no events in both sitagliptin and non-exposed groups are excluded from the treatment comparison. RR denotes adjusted incidence rate ratio. 
related event. The exposure-adjusted incidence rate was 0.00 per 100 patient-years with sitagliptin and 0.86 with sulphonylurea (adjusted incidence rate ratio $=0.00[95 \%$ CI: $0.00,0.31]$, reflective of no events in the sitagliptin group). There were no cardiovascular-related deaths in the sitagliptin group compared to 5 in the sulphonylurea group. The exposure-adjusted incidence rate for cardiovascular-related death was 0.00 per 100 -patientyears with sitagliptin and 0.39 with sulphonylurea (adjusted incidence rate ratio $=0.00$ [95\% CI: 0.00, 0.81]). In the sensitivity analysis that included all blinded exposure to sitagliptin $100 \mathrm{mg}$ or a sulphonylurea ( $\mathrm{n}=1,897$ on sitagliptin, $\mathrm{n}=1,389$ on a sulphonylurea), the cumulative patient exposure was 2,044 patient-years for the sitagliptin group and 1,486 patient-years for the sulphonylurea group. A total of 24 patients had at least one MACErelated event reported, with 11 in the sitagliptin group and 13 in the sulphonylurea group. The exposure-adjusted incidence rate was 0.54 per 100 patient-years in the sitagliptin group and 0.87 in the non-exposed group (adjusted incidence rate ratio $=0.41$ [95\% CI: 0.17, 0.96]).

In sensitivity analyses for each of the cohorts evaluated, nearly identical adjusted incidence rate ratios were found for those in the MACE and death analyses using the Mantel-Haenszel method and the adjusted hazard ratios from Cox regression (data not shown).

\section{Discussion}

In this pooled analysis of 14,611 patients from 25 clinical studies, treatment with sitagliptin was not associated with an increased risk of cardiovascular events relative to the control treatments used in the studies (both active and placebo). The present results extend and confirm the previously reported cardiovascular safety findings with sitagliptin [16]. To control for the confounding effects of pooling active comparators, the present analysis also examined the effects of sitagliptin versus placebo on cardiovascular safety and found no increased risk of cardiovascular events with sitagliptin. Furthermore, cardiovascular-related analyses with other DPP-4 inhibitors support the present findings of no evidence of cardiovascular harm [17-20]. In these other analyses, there also tended to be a numerical reduction in risk of cardiovascular events with DPP-4 inhibitors relative to non-exposure to DPP-4 inhibitors. Recently, when Monami et al. [33] combined the results of randomised clinical trials for DPP-4 inhibitors in a meta-analysis, a significant reduction in risk for MACE-related events was found with DPP-4 inhibitors. These findings need to be confirmed in prospective studies appropriately designed to assess cardiovascular outcomes. For sitagliptin, a placebo-controlled study assessing cardiovascular outcomes is currently underway in patients at increased risk for cardiovascular events (Clinicaltrials. gov: NCT00790205; [34]).

In a subanalysis of three studies comparing treatment with sitagliptin to sulphonylureas in patients with type 2 diabetes mellitus, a lower incidence and risk of MACErelated events was observed with sitagliptin compared to sulphonylurea. In the sensitivity analysis including all blinded exposure to sitagliptin or sulphonylurea and more reported events overall, a similar trend was observed. A lower incidence of cardiovascular events was also reported with linagliptin compared to glimepiride in a two-year trial [35]. The comparison between linagliptin and glimepiride is being further assessed in a long-term cardiovascular outcomes trial (Clinicaltrial.gov: NCT 01243424). These observations could reflect a deleterious effect of sulphonylureas, a beneficial effect of DPP-4 inhibitors, or a combination of both. While DPP-4 inhibitors and sulphonylureas both enhance insulin secretion, there are differences in their mechanisms of action, which have the potential for impacting cardiovascular safety.

Sulphonylureas bind to the SUR subunit (subtype SUR1) of the potassium ATP $\left(\mathrm{K}_{\mathrm{ATP}}\right)$ channel in the beta cell membrane and by inhibiting $\mathrm{K}_{\mathrm{ATP}}$ channel activity, increase insulin release irrespective of ambient glucose concentrations [36]. Incretin-mediated enhancement of insulin release, in contrast, is glucose-dependent [15]. As a result of the mechanisms of action, hypoglycaemia is a common side effect with sulphonylurea therapy [37], whereas rates of hypoglycaemia with incretin-based therapies are not increased relative to placebo [38]. For example, in the three studies used for the present pooled analysis, there was a 3- to 6-fold increase in the incidence of symptomatic hypoglycaemia with sulphonylurea compared with sitagliptin [27-30]. Hypoglycaemia is associated with ischaemic complications in diabetic subjects [39]. Additionally, sulphonylureas bind to the SUR receptor (subtype SUR2) on cardiac myocytes and on endothelial cells, and thus may have direct effects on cardiovascular function [40]. Sulphonylureas have also been shown to abolish the beneficial effects of ischaemic preconditioning, a protective mechanism whereby a brief period of ischaemia is cardioprotective for subsequent periods of prolonged ischaemia $[41,42]$.

Sulphonylureas are widely used as pharmacologic therapy in patients with type 2 diabetes mellitus. A concern regarding the potential for sulphonylurea-induced cardiovascular toxicity was first raised as a result of the University Group Diabetes Program (UGDP) study, in which an increase in mortality was observed with tolbutamide compared to both insulin and to placebo [43]. While controversy ensued regarding the validity of these findings $[44,45]$ and their applicability to other drugs in this class, a warning regarding the increased risk of cardiovascular mortality was introduced and remains in the 
product information for all sulphonylureas marketed in the United States. Long-term prospective clinical studies have not reported an increased risk of cardiovascular events or mortality with sulphonylurea relative to other treatments in patients with recently- or newly-diagnosed type 2 diabetes mellitus $[46,47]$. However, many, but not all, observational studies have found an association between sulphonylurea use and an increase in cardiovascular events or mortality [21-25]. Of note, metformin was a main comparator in these observational studies and any differences could be attributed to the cardiovascular benefit of metformin [48] rather than a risk related to sulphonylurea. The combination of metformin and sulphonylurea has been associated with an increased risk of death in a sub-study of UKPDS 34 [48] or the composite endpoint of hospitalization for cardiovascular disease or mortality in a meta-analysis of observational studies [49]. These results have not been confirmed in a randomized, prospective clinical study.

In contrast to the data suggesting a detrimental effect of sulphonylureas on cardiovascular outcomes, preclinical and clinical mechanistic studies have suggested potential benefits of incretins and incretin-based therapies, such as DPP-4 inhibitors or GLP-1 agonists, on cardiovascular function and outcomes [50,51]. In animals, GLP-1 infusion protected the rat myocardium against ischaemia reperfusion injury [52,53]. Genetically-modified mice that are lacking the DPP-4 enzyme had improved survival post-myocardial infarction; similar protection was observed in normal mice treated with sitagliptin $[54,55]$. In humans, GLP-1 infusion enhanced endothelial function, as measured by forearm blood flow in response to acetylcholine; interestingly, coadministration of the sulphonylurea glyburide, but not glimepiride, abolished GLP-1 induced augmentation of forearm blood flow [56]. GLP-1 infusion also improved left ventricular ejection and contractile function in patients with acute myocardial infarction [57]. In a study of patients with coronary artery disease awaiting revascularisation, sitagliptin treatment was associated with improvement in left ventricular performance in response to dobutamine-induced stress and with mitigation of post-ischaemic stunning [58].

While the potential benefits of DPP-4 inhibition have been primarily attributed to the enhancement of GLP-1 activity, other endogenous substrates of DPP-4 could be relevant to cardiovascular function and outcomes. Treatment with sitagliptin increased plasma levels of stromalderived factor- $1 \alpha$ (SDF-1 $\alpha)$ and circulating endothelial progenitor cells, while also reducing plasma monocyte chemoattractant protein-1, a proinflammatory chemokine, in patients with type 2 diabetes mellitus [59]. SDF-1 $\alpha$, a chemokine, attracts stem cells to ischaemic sites and enhances post-ischaemia angiogenesis [60]. Zaruba et al. [61] found that, in mice in which myocardial infarction was induced via surgical ligation of the left anterior descending artery, coadministration of granulocytecolony-stimulating factor (GCSF; to stimulate stem cell mobilisation) with a DPP-4 inhibitor resulted in increased myocardial homing of circulating CXCR-4+ stem cells, reduced cardiac remodeling, and improved heart function and survival. A clinical trial assessing the safety and efficacy of sitagliptin in combination with GCSF in patients with acute myocardial infarction is currently underway [62].

The present results should be interpreted with caution because of the post hoc nature of this analysis and the clinical studies were not specifically designed to assess cardiovascular outcomes. Additionally, the case definition used in the analysis was based on reports of adverse events that matched MACE-related terms using the Medical Dictionary for Regulatory Activities and on cardiovascular-related deaths, rather than on the results of a formal process of adjudication of reported events. Any potential impact of rosiglitazone on the present findings was likely minimal, as rosiglitazone therapy was included in only two of the twenty-five studies. In one study in which rosiglitazone was a comparator agent, there were no MACE-related events reported. In the other study that had three MACE-related events, rosiglitazone and metformin were background therapy in both the sitagliptin and non-exposed groups.

The strengths of this analysis include the pooling of data from randomized controlled trials, the use of patient-level data, and a large sample size. The potential influence of baseline characteristics on outcomes was controlled by using studies in which patients were randomly assigned to treatment groups. Lastly, numerous supporting analyses confirmed the primary findings.

In summary, these analyses suggest that treatment with sitagliptin does not increase cardiovascular risk in patients with type 2 diabetes mellitus. In a subanalysis, a higher rate of cardiovascular morbidity and mortality was associated with sulphonylurea therapy relative to sitagliptin. Whether this observation is related to a deleterious effect of sulphonylurea therapy, a protective effect of sitagliptin, or a combination of the two is unknown at this time and will require future research.

\section{Appendix I:}

This analysis used a pooled population $(\mathrm{N}=14,611)$ drawn from all 25 multicenter, U.S. or multinational, double-blind, parallel-group studies conducted by Merck \& Co., Inc., in which patients were randomised to receive sitagliptin $100 \mathrm{mg} /$ day $(\mathrm{n}=7,726)$ or a comparator $(\mathrm{n}=6,885)$ for at least 12 weeks and up to 2 years (the duration of the longest studies) and for which results were available as of December 1, 2011. Specific studies and treatment arms are listed in Table 2. 
Table 2 Studies and treatment arms included in pooled analysis

\begin{tabular}{|c|c|c|c|c|c|c|}
\hline Study & Study design & $\begin{array}{c}\text { Sitagliptin } 100 \mathrm{mg} / \text { day group } \\
(\mathrm{N}=7195)\end{array}$ & $\mathbf{n}$ & $\begin{array}{l}\text { Non-exposed group } \\
(\mathrm{N}=6267)^{\S}\end{array}$ & $\mathrm{n}$ & Reference* \\
\hline P010: twice-daily dose-range finding & $\begin{array}{l}\text { 106-week active-controlled } \\
\text { period }\end{array}$ & $\begin{array}{l}\text {-Sitagliptin } 50 \text { mg b.i.d. switched } \\
\text { to sitagliptin } 100 \text { mg q.d. }\end{array}$ & 122 & -Glipizide & 123 & {$[27]^{+}$} \\
\hline P014: once-daily dose-range finding & $\begin{array}{l}\text { 12-week placebo-controlled } \\
\text { period and 94-week active- } \\
\text { controlled period }\end{array}$ & $\begin{array}{l}\text {-Sitagliptin } 100 \mathrm{mg} \text { q.d. } \\
\text {-Sitagliptin } 50 \mathrm{mg} \text { b.i.d. switched } \\
\text { to sitagliptin } 100 \mathrm{mg} \text { q.d. }\end{array}$ & $\begin{array}{l}110 \\
111\end{array}$ & $\begin{array}{l}\text {-Placebo ( } 12 \text { weeks) } \\
\text { switched to metformin } \\
\text { ( } 94 \text { weeks) }\end{array}$ & 111 & {$[63]^{t+}$} \\
\hline $\begin{array}{l}\text { P019: placebo-controlled add-on to } \\
\text { pioglitazone study }\end{array}$ & $\begin{array}{l}\text { 24-week placebo-controlled } \\
\text { period }\end{array}$ & -Sitagliptin 100 mg q.d. & 175 & -Placebo & 178 & {$[64]^{++}$} \\
\hline $\begin{array}{l}\text { P020: placebo-controlled add-on to } \\
\text { metformin study }\end{array}$ & $\begin{array}{l}\text { 24-week placebo-controlled } \\
\text { period and } 80 \text {-week active- } \\
\text { controlled period }\end{array}$ & -Sitagliptin 100 mg q.d. & 464 & $\begin{array}{l}\text {-Placebo ( } 24 \text { weeks) } \\
\text { switched to glipizide }\end{array}$ & 237 & {$[65]^{++}$} \\
\hline $\begin{array}{l}\text { P021: placebo-controlled } \\
\text { monotherapy study }\end{array}$ & $\begin{array}{l}\text { 24-week placebo-controlled } \\
\text { period }\end{array}$ & -Sitagliptin 100 mg q.d. & 238 & -Placebo & 253 & {$[66]^{++}$} \\
\hline $\begin{array}{l}\text { P023: placebo-controlled } \\
\text { monotherapy study }\end{array}$ & $\begin{array}{l}\text { 18-week placebo-controlled } \\
\text { period and 36-week active- } \\
\text { controlled period }\end{array}$ & -Sitagliptin 100 mg q.d. & 205 & $\begin{array}{l}\text {-Placebo ( } 18 \text { weeks) } \\
\text { switched to pioglitazone } \\
\text { ( } 36 \text { weeks) }\end{array}$ & 110 & {$[67]^{++}$} \\
\hline $\begin{array}{l}\text { P024: active-controlled add-on to } \\
\text { metformin study }\end{array}$ & $\begin{array}{l}\text { 104-week active-controlled } \\
\text { period }\end{array}$ & -Sitagliptin 100 mg q.d. & 588 & -Glipizide & 584 & {$[28,29]^{\dagger}$} \\
\hline $\begin{array}{l}\text { P035: placebo-controlled add-on to } \\
\text { glimepiride, alone or in combination } \\
\text { with metformin study }\end{array}$ & $\begin{array}{l}\text { 24-week placebo-controlled } \\
\text { period and 30-week active- } \\
\text { controlled period }\end{array}$ & -Sitagliptin 100 mg q.d. & 222 & $\begin{array}{l}\text {-Placebo ( } 24 \text { weeks) } \\
\text { switched to pioglitazone } \\
\text { ( } 30 \text { weeks) }\end{array}$ & 219 & {$[68]^{++}$} \\
\hline $\begin{array}{l}\text { P036: placebo- and active-controlled } \\
\text { study of initial combination use of } \\
\text { sitagliptin and metformin }\end{array}$ & $\begin{array}{l}\text { 24-week placebo-controlled } \\
\text { period; } 80 \text {-week active- } \\
\text { controlled period }\end{array}$ & $\begin{array}{l}\text {-Sitagliptin } 100 \text { mg q.d. } \\
\text {-Sitagliptin } 50 \text { mg b.i.d. + } \\
\text { metformin } 500 \text { mg b.i.d. } \\
\text {-Sitagliptin } 50 \text { mg b.i.d. + } \\
\text { metformin } 1000 \text { mg b.i.d. }\end{array}$ & $\begin{array}{l}179 \\
190 \\
182\end{array}$ & $\begin{array}{l}\text {-Placebo ( } 24 \text { weeks) } \\
\text { switched to metformin } \\
\text { ( } 80 \text { weeks) } \\
\text {-Metformin } 500 \mathrm{mg} \\
\text { b.i.d. } \\
\text {-Metformin } 1000 \mathrm{mg} \\
\text { b.i.d. }\end{array}$ & $\begin{array}{l}176 \\
182\end{array}$ & {$[69-71]^{++}$} \\
\hline $\begin{array}{l}\text { P040: placebo-controlled } \\
\text { monotherapy study }\end{array}$ & $\begin{array}{l}\text { 18-week placebo-controlled } \\
\text { period }\end{array}$ & -Sitagliptin 100 mg q.d. & 352 & -Placebo & 178 & {$[72]^{++}$} \\
\hline $\begin{array}{l}\text { P047: placebo-controlled } \\
\text { monotherapy study in elderly } \\
\text { patients }\end{array}$ & $\begin{array}{l}\text { 24-week placebo-controlled } \\
\text { period }\end{array}$ & -Sitagliptin 100 mg q.d. & 91 & -Placebo & 92 & {$[73]^{t+}$} \\
\hline $\begin{array}{l}\text { P049: active-controlled monotherapy } \\
\text { study }\end{array}$ & $\begin{array}{l}\text { 24-week active-controlled } \\
\text { period }\end{array}$ & -Sitagliptin 100 mg q.d. & 528 & -Metformin & 522 & {$[74]$} \\
\hline $\begin{array}{l}\text { P051: placebo-controlled add-on to } \\
\text { insulin, alone or in combination with } \\
\text { metformin study }\end{array}$ & $\begin{array}{l}\text { 24-week placebo-controlled } \\
\text { period }\end{array}$ & -Sitagliptin 100 mg q.d. & 322 & -Placebo & 319 & {$[75]^{++}$} \\
\hline $\begin{array}{l}\text { P052: placebo-controlled add-on to } \\
\text { metformin and rosiglitazone study }\end{array}$ & $\begin{array}{l}\text { 54-week placebo-controlled } \\
\text { period }\end{array}$ & -Sitagliptin 100 mg q.d. & 170 & -Placebo & 92 & {$[76]^{t+}$} \\
\hline $\begin{array}{l}\text { P053: placebo-controlled add-on to } \\
\text { metformin study }\end{array}$ & $\begin{array}{l}\text { 30-week placebo-controlled } \\
\text { period }\end{array}$ & -Sitagliptin 100 mg q.d. & 96 & -Placebo & 94 & {$[77]^{++}$} \\
\hline \multirow{2}{*}{$\begin{array}{l}\text { P061: placebo- and active-controlled } \\
\text { mechanism of action factorial study }\end{array}$} & \multirow{2}{*}{$\begin{array}{l}\text { 12-week placebo-controlled } \\
\text { period }\end{array}$} & \multirow{2}{*}{$\begin{array}{l}\text {-Sitagliptin } 100 \mathrm{mg} \text { q.d. } \\
\text {-Sitagliptin } 100 \mathrm{mg} \text { q.d. + } \\
\text { pioglitazone }\end{array}$} & 52 & -Pioglitazone & 54 & \multirow{2}{*}[78]{$^{++}$} \\
\hline & & & 52 & -Placebo & 53 & \\
\hline $\begin{array}{l}\text { P064: active-controlled study of } \\
\text { initial combination use of sitagliptin } \\
\text { and pioglitazone }\end{array}$ & $\begin{array}{l}\text { 54-week active-controlled } \\
\text { period }\end{array}$ & $\begin{array}{l}\text {-Sitagliptin } 100 \mathrm{mg} \text { q.d. + } \\
\text { pioglitazone }\end{array}$ & 261 & -Pioglitazone & 259 & {$[79,80]^{+\dagger}$} \\
\hline $\begin{array}{l}\text { P066: active-controlled study of } \\
\text { combination use of sitagliptin/ } \\
\text { metformin FDC }\end{array}$ & $\begin{array}{l}\text { 32-week active-controlled } \\
\text { period }\end{array}$ & $\begin{array}{l}\text {-Sitagliptin } 50 \mathrm{mg}+\text { metformin } \\
1000 \text { mg b.i.d. (FDC) }\end{array}$ & 261 & $\begin{array}{l}\text {-Pioglitazone } 45 \mathrm{mg} \\
\text { q.d. }\end{array}$ & 256 & {$[81]$} \\
\hline $\begin{array}{l}\text { P068: active-controlled study of } \\
\text { sitagliptin and combination use of } \\
\text { sitagliptin/metformin FDC }\end{array}$ & $\begin{array}{l}\text { 40-week active-controlled } \\
\text { period }\end{array}$ & $\begin{array}{l}\text {-Sitagliptin } 100 \mathrm{mg} \text { q.d. switched } \\
\text { to sitagliptin } 50 \mathrm{mg}+\text { metformin } \\
1000 \mathrm{mg} \text { b.i.d. (FDC) }\end{array}$ & 244 & $\begin{array}{l}\text {-Pioglitazone } 15 \mathrm{mg} \\
\text { q.d. titrated up to } \\
45 \mathrm{mg} \text { q.d. }\end{array}$ & 247 & {$[82]$} \\
\hline $\begin{array}{l}\text { P074: placebo-controlled add-on to } \\
\text { metformin study }\end{array}$ & $\begin{array}{l}\text { 24-week placebo-controlled } \\
\text { period }\end{array}$ & -Sitagliptin 100 mg q.d. & 197 & -Placebo & 198 & {$[83]^{+\dagger}$} \\
\hline $\begin{array}{l}\text { P079: active-controlled study of } \\
\text { initial combination use of sitagliptin/ } \\
\text { metformin FDC }\end{array}$ & $\begin{array}{l}\text { 44-week active-controlled } \\
\text { period }\end{array}$ & $\begin{array}{l}\text {-Sitagliptin } 50 \mathrm{mg}+\text { metformin } \\
1000 \text { mg b.i.d. (FDC) }\end{array}$ & 625 & $\begin{array}{l}\text {-Metformin } 1000 \mathrm{mg} \\
\text { b.i.d. (FDC) }\end{array}$ & 621 & {$[84,85]^{+\dagger}$} \\
\hline
\end{tabular}


Table 2 Studies and treatment arms included in pooled analysis (Continued)

\begin{tabular}{|c|c|c|c|c|c|c|}
\hline $\begin{array}{l}\text { P102: active-controlled study of } \\
\text { initial combination use of sitagliptin } \\
\text { and pioglitazone }\end{array}$ & $\begin{array}{l}\text { 54-week active-controlled } \\
\text { period }\end{array}$ & $\begin{array}{l}\text {-Sitagliptin } 100 \text { mg q.d. } \\
\text {-Sitagliptin } 50 \text { mg b.i.d. + } \\
\text { pioglitazone } 15 \text { mg q.d. } \\
\text {-Sitagliptin } 50 \text { mg b.i.d. + } \\
\text { pioglitazone } 30 \text { mg q.d. } \\
\text {-Sitagliptin } 50 \text { mg b.i.d. + } \\
\text { pioglitazone } 45 \text { mg q.d. }\end{array}$ & $\begin{array}{l}231 \\
230 \\
231 \\
230\end{array}$ & $\begin{array}{l}\text {-Pioglitazone } 15 \text { mg } \\
\text { q.d. } \\
\text {-Pioglitazone } 30 \text { mg } \\
\text { q.d. } \\
\text {-Pioglitazone } 45 \text { mg } \\
\text { q.d. }\end{array}$ & $\begin{array}{l}230 \\
233\end{array}$ & {$[86]^{t+}$} \\
\hline $\begin{array}{l}\text { P128: placebo-controlled add-on to } \\
\text { metformin and pioglitazone study }\end{array}$ & $\begin{array}{l}\text { 26-week placebo-controlled } \\
\text { period }\end{array}$ & -Sitagliptin 100 mg q.d. & 157 & -Placebo & 156 & {$[87]^{++}$} \\
\hline $\begin{array}{l}\text { P801: placebo- and active-controlled } \\
\text { add-on to metformin study }\end{array}$ & $\begin{array}{l}\text { 18-week placebo-controlled } \\
\text { period }\end{array}$ & -Sitagliptin 100 mg q.d. & 94 & $\begin{array}{l}\text {-Rosiglitazone } 8 \text { mg q.d. } \\
\text {-Placebo }\end{array}$ & $\begin{array}{l}87 \\
91\end{array}$ & {$[88]^{+\dagger}$} \\
\hline $\begin{array}{l}\text { P803: active-controlled add-on to } \\
\text { metformin study }\end{array}$ & $\begin{array}{l}\text { 30-week active-controlled } \\
\text { period }\end{array}$ & -Sitagliptin 100 mg q.d. & 516 & -Glimepiride & 518 & {$[30]^{+}$} \\
\hline \multicolumn{7}{|c|}{$\begin{array}{l}\text { * References are for the initial phases of the studies that had extension or continuation phases, unless a reference is provided for the results beyond the initial } \\
\text { phase. } \\
\$ \text { This column reflects the blinded treatment(s) to which patients were randomised. For studies identified in column } 1 \text { as "add-on" studies, all patients also } \\
\text { received the active therapy indicated in column } 1 \text { (open-label). } \\
+ \text { Studies included in the primary Sitagliptin vs. Sulphonylurea comparison. } \\
+ \text { Studies included in the primary Sitagliptin vs. Placebo comparison. This comparison included studies where patients were randomised to sitagliptin or placebo } \\
\text { as monotherapy (e.g., P021) or as add-on therapy (e.g., P019), as well as studies where patients were randomised to sitagliptin + active agent or active agent } \\
\text { (e.g., P102). The control groups of studies in the latter category included a sitagliptin-matched placebo for purposes of blinding. For studies where the placebo } \\
\text { control group switched to active therapy at a post-randomisation time point (e.g., P020), only the placebo-controlled portion of the study was included. } \\
\text { q.d. = once daily; b.i.d. = twice daily; FDC = fixed-dose combination tablet. }\end{array}$} \\
\hline
\end{tabular}

\section{Appendix II: Definition of major adverse cardiovascular events (MACE)}

Any adverse event with a Medical Dictionary for Regulatory Activities (MedDRA, version 14.1) term in the following list (Table 3) was classified as MACE. Asterisks indicate the MedDRA terms that were reported in the present analyses.

\section{Table 3 MACE terms}

\begin{tabular}{ll}
\hline Acute myocardial infarction* & Haemorrhagic cerebral infarction \\
\hline Basal ganglia infarction & Haemorrhagic stroke* \\
\hline Basilar artery thrombosis & Haemorrhagic transformation stroke \\
\hline Brain stem infarction* & Ischaemic cerebral infarction \\
\hline Brain stem stroke & Ischaemic stroke* \\
\hline Brain stem thrombosis & Lacunar infarction* \\
\hline Carotid arterial embolus & Lateral medullary syndrome \\
\hline Carotid artery thrombosis & Moyamoya disease \\
\hline Cerebellar artery thrombosis & Myocardial infarction* \\
\hline Cerebellar embolism & Papillary muscle infarction \\
\hline Cerebellar infarction* & Post procedural myocardial infarction \\
\hline Cerebral artery embolism & Post procedural stroke \\
\hline Cerebral artery thrombosis & Silent myocardial infarction* \\
\hline Cerebral infarction* & Stroke in evolution \\
\hline Cerebral thrombosis & Sudden cardiac death* \\
\hline Cerebrovascular accident* & Thalamic infarction* \\
\hline Coronary artery thrombosis & Thrombotic cerebral infarction \\
\hline Coronary bypass thrombosis & Thrombotic stroke \\
\hline Embolic cerebral infarction & Wallenberg syndrome \\
\hline Embol stoke &
\end{tabular}

Embolic stroke
Additionally, all deaths determined to be potentially cardiovascular-related (based on blinded clinical review) were classified as MACE. The reported MedDRA terms for the MACE-related events classified as cardiovascular (CV) deaths were as follows (Table 4):
Table 4 MACE-related cardiovascular death terms

\begin{tabular}{ll}
\hline Acute myocardial infarction & Fall \\
\hline Cardio-respiratory arrest & Haemorrhagic stroke \\
\hline Cerebral ischaemia & Ischaemic stroke \\
\hline Coronary artery disease & Myocardial infarction \\
\hline Coronary artery insufficiency & Myocardial ischaemia \\
\hline Death & Sudden cardiac death \\
\hline
\end{tabular}

Drowning

\section{Competing interests}

All authors are employees of Merck Sharp \& Dohme Corp., a subsidiary of Merck \& Co., Inc., Whitehouse Station, NJ, the manufacturer of sitagliptin and may have stock or stock options in the company.

\section{Authors' contributions}

SSE, GTG, DS, KDK, and BJG conceived the design for the analyses. GTG performed the statistical analyses. All authors were involved in the interpretation of the analyses. All authors were involved in drafting the manuscript or revising it critically for important intellectual content. All authors approved the final manuscript.

\section{Funding}

All studies and analyses described in this review were funded by Merck Sharp \& Dohme Corp., a subsidiary of Merck \& Co., Inc., Whitehouse Station, NJ. 
Received: 18 September 2012 Accepted: 6 December 2012

Published: 3 January 2013

\section{References}

1. Stratton IM, Adler Al, Neil HA, Matthews DR, Manley SE, Cull CA, et al: Association of glycaemia with macrovascular and microvascular complications of type 2 diabetes (UKPDS 35): prospective observational study. BMJ 2000, 321:405-412.

2. Stamler J, Vaccaro O, Neaton JD, Wentworth D: Diabetes, other risk factors, and 12-yr cardiovascular mortality for men screened in the Multiple Risk Factor Intervention Trial. Diabetes Care 1993, 16:434-444.

3. Centers for Disease Control and Prevention: National diabetes fact sheet: national estimates and general information on diabetes and prediabetes in the United States, 2011. Atlanta, GA: U.S. Department of Health and Human Services, Centers for Disease Control and Prevention; 2011.

4. Eliasson M, Jansson JH, Lundblad D, Naslund U: The disparity between long-term survival in patients with and without diabetes following a first myocardial infarction did not change between 1989 and 2006: an analysis of 6,776 patients in the Northern Sweden MONICA Study. Diabetologia 2011, 54:2538-2543.

5. Mukamal KJ, Nesto RW, Cohen MC, Muller JE, Maclure M, Sherwood JB, et al: Impact of diabetes on long-term survival after acute myocardial infarction: comparability of risk with prior myocardial infarction. Diabetes Care 2001, 24:1422-1427.

6. Lee KL, Woodlief LH, Topol EJ, Weaver WD, Betriu A, Col J, et al: Predictors of 30-day mortality in the era of reperfusion for acute myocardia infarction. Results from an international trial of 41,021 patients. GUSTO-I Investigators. Circulation 1995, 91:1659-1668.

7. Abbott RD, Donahue RP, Kannel WB, Wilson PW: The impact of diabetes on survival following myocardial infarction in men vs women. The Framingham Study. JAMA 1988, 260:3456-3460.

8. Miettinen $H$, Lehto S, Salomaa V, Mahonen M, Niemela M, Haffner SM, et al: Impact of diabetes on mortality after the first myocardial infarction. The FINMONICA Myocardial Infarction Register Study Group. Diabetes Care 1998, 21:69-75.

9. Haffner SM, Lehto S, Ronnemaa T, Pyorala K, Laakso M: Mortality from coronary heart disease in subjects with type 2 diabetes and in nondiabetic subjects with and without prior myocardial infarction. N Engl J Med 1998, 339:229-234.

10. Grundy SM, Cleeman Jl, Merz CN, Brewer HB Jr, Clark LT, Hunninghake DB, et al: Implications of recent clinical trials for the National Cholesterol Education Program Adult Treatment Panel III guidelines. Circulation 2004, 110:227-239.

11. Nissen SE, Wolski K: Effect of rosiglitazone on the risk of myocardial infarction and death from cardiovascular causes. N Engl J Med 2007, 356:2457-2471.

12. Singh S, Loke YK, Furberg CD: Long-term risk of cardiovascular events with rosiglitazone: a meta-analysis. JAMA 2007, 298:1189-1195.

13. Lipscombe LL, Gomes T, Levesque LE, Hux JE, Juurlink DN, Alter DA: Thiazolidinediones and cardiovascular outcomes in older patients with diabetes. JAMA 2007, 298:2634-2643.

14. Guidance for Industry: Diabetes mellitus - evaluating cardiovascular risk in new antidiabetic therapies to treat type 2 diabetes. Washington, DC: U.S. Department of Health and Human Services, Food and Drug Administration, Center for Drug Evaluation and Research (CDER); 12/2008. www.fda.gov/downloads/Drugs/ GuidanceComplianceRegulatoryInformation/Guidances/ucm071627.pdf.

15. Drucker DJ, Nauck MA: The incretin system: glucagon-like peptide-1 receptor agonists and dipeptidyl peptidase- 4 inhibitors in type 2 diabetes. Lancet 2006, 368:1696-1705.

16. Williams-Herman D, Engel SS, Round E, Johnson J, Golm GT, Guo H, et al: Safety and tolerability of sitagliptin in clinical studies: a pooled analysis of data from 10,246 patients with type 2 diabetes. BMC Endocr Disord 2010, 10:7.

17. Cobble ME, Frederich R: Saxagliptin for the treatment of type 2 diabetes mellitus: assessing cardiovascular data. Cardiovasc Diabetol 2012, 11:6.

18. Schweizer A, Dejager S, Foley JE, Couturier A, Ligueros-Saylan M, Kothny W: Assessing the cardio-cerebrovascular safety of vildagliptin: meta-analysis of adjudicated events from a large Phase III type 2 diabetes population. Diabetes Obes Metab 2010, 12:485-494.

19. Johansen OE, Neubacher D, von Eynatten M, Patel S, Woerle HJ: Cardiovascular safety with linagliptin in patients with type 2 diabetes mellitus: a pre-specified, prospective, and adjudicated meta-analysis of a phase 3 programme. Cardiovasc Diabetol 2012, 11:3.

20. White WB, Gorelick PB, Fleck P, Smith N, Wilson C, Pratley R: Cardiovascular events in patients receiving alogliptin: a pooled analysis of randomized clinical trials (abstract). Diabetes 2010, 59(Suppl 1):A105.

21. Johnson JA, Simpson SH, Toth EL, Majumdar SR: Reduced cardiovascular morbidity and mortality associated with metformin use in subjects with Type 2 diabetes. Diabet Med 2005, 22:497-502.

22. Evans JM, Ogston SA, Emslie-Smith A, Morris AD: Risk of mortality and adverse cardiovascular outcomes in type 2 diabetes: a comparison of patients treated with sulfonylureas and metformin. Diabetologia 2006, 49:930-936.

23. Johnson JA, Majumdar SR, Simpson SH, Toth EL: Decreased mortality associated with the use of metformin compared with sulfonylurea monotherapy in type 2 diabetes. Diabetes Care 2002, 25:2244-2248.

24. Tzoulaki I, Molokhia M, Curcin V, Little MP, Millett CJ, Ng A, et al: Risk of cardiovascular disease and all cause mortality among patients with type 2 diabetes prescribed oral antidiabetes drugs: retrospective cohort study using UK general practice research database. BMJ 2009, 339:b4731.

25. Jorgensen $\mathrm{CH}$, Gislason $\mathrm{GH}$, Andersson C, Ahlehoff $\mathrm{O}$, Charlot M, Schramm $\mathrm{TK}$, et al: Effects of oral glucose-lowering drugs on long term outcomes in patients with diabetes mellitus following myocardial infarction not treated with emergent percutaneous coronary intervention-a retrospective nationwide cohort study. Cardiovasc Diabetol 2010, 9:54.

26. Pantalone KM, Kattan MW, Yu C, Wells BJ, Arrigain S, Jain A, et al: The risk of developing coronary artery disease or congestive heart failure, and overall mortality, in type 2 diabetic patients receiving rosiglitazone, pioglitazone, metformin, or sulfonylureas: a retrospective analysis. Acta Diabetol 2009, 46:145-154.

27. Scott R, Wu M, Sanchez M, Stein P: Efficacy and tolerability of the dipeptidyl peptidase-4 inhibitor sitagliptin as monotherapy over 12 weeks in patients with type 2 diabetes. Int J Clin Pract 2007, 61:171-180.

28. Nauck MA, Meininger G, Sheng D, Terranella L, Stein PP: Efficacy and safety of the dipeptidyl peptidase-4 inhibitor, sitagliptin, compared with the sulfonylurea, glipizide, in patients with type 2 diabetes inadequately controlled on metformin alone: a randomized, double-blind, non-inferiority trial. Diabetes Obes Metab 2007, 9:194-205.

29. Seck T, Nauck MA, Sheng D, Sunga S, Davies MJ, Stein PP, et al: Safety and efficacy of treatment with sitagliptin or glipizide in patients with type 2 diabetes inadequately controlled on metformin: A 2-year study. Int J Clin Pract 2010, 64:562-576.

30. Arechavaleta R, Seck T, Chen Y, Krobot KJ, O'Neill EA, Duran L, et al: Efficacy and safety of treatment with sitagliptin or glimepiride in patients with type 2 diabetes inadequately controlled on metformin monotherapy: a randomized, double-blind, non-inferiority trial. Diabetes Obes Metab 2011, 13:160-168.

31. Breslow NE, Day NE: Statistical methods in cancer research. Volume II--The design and analysis of cohort studies. IARC Sci Publ No. 82. Geneva: WHO Press; 1987.

32. Robins J, Breslow N, Greenland S: Estimators of the Mantel-Haenszel variance consistent in both sparse data and large-strata limiting models. Biometrics 1986, 42:311-323.

33. Monami M, Ahren B, Dicembrini I, Mannucci E: Dipeptidyl peptidase-4 inhibitors and cardiovascular risk: a meta-analysis of randomized clinical trials. Diabetes Obes Metab, . doi:101111/dom.12000 (epub ahead of print Aug 23, 2012).

34. Bethel MA, Green J, Califf RM, Holman RR: Rationale and design of the Trial Evaluating Cardiovascular Outcomes with Sitagliptin (TECOS) (abstract). Diabetologia 2009, 52(Suppl 1):S480.

35. Gallwitz B, Rosenstock J, Rauch T, Bhattacharya S, Patel S, von Eynatten M, et al: 2-year efficacy and safety of linagliptin compared with glimepiride in patients with type 2 diabetes inadequately controlled on metformin: a randomised, double-blind, non-inferiority trial. Lancet 2012, 380:475-483.

36. Abdelmoneim AS, Hasenbank SE, Seubert JM, Brocks DR, Light PE, Simpson $\mathrm{SH}$ : Variations in tissue selectivity amongst insulin secretagogues: a systematic review. Diabetes Obes Metab 2012, 14:130-138.

37. Inzucchi SE: Oral antihyperglycemic therapy for type 2 diabetes: scientific review. JAMA 2002, 287:360-372.

38. Drucker DJ, Sherman SI, Bergenstal RM, Buse JB: The safety of incretinbased therapies-review of the scientific evidence. J Clin Endocrinol Metab 2011, 96:2027-2031.

39. Wright RJ, Frier BM: Vascular disease and diabetes: is hypoglycaemia an aggravating factor? Diabetes Metab Res Rev 2008, 24:353-363. 
40. Ye Y, Perez-Polo JR, Aguilar D, Birnbaum Y: The potential effects of antidiabetic medications on myocardial ischemia-reperfusion injury. Basic Res Cardiol 2011, 106:925-952

41. Meier JJ, Gallwitz B, Schmidt WE, Mugge A, Nauck MA: Is impairment of ischaemic preconditioning by sulfonylurea drugs clinically important? Heart 2004, 90:9-12.

42. Kar P, Holt Rl: The effect of sulphonylureas on the microvascular and macrovascular complications of diabetes. Cardiovasc Drugs Ther 2008, 22:207-213.

43. The University Group Diabetes Program: A study of the effects of hypoglycemic agents on vascular complications in patients with adultonset diabetes. Mortality results. Diabetes 1970, 19(Suppl 1):789-830.

44. Seltzer HS: A summary of criticisms of the findings and conclusions of the University Group Diabetes Program (UGDP). Diabetes 1972, 21:976-979.

45. American diabetes association policy statement: the UGDP controversy Diabetes Care 1979, 2:1-3.

46. UK Prospective Diabetes Study (UKPDS) Group: Intensive blood-glucose control with sulphonylureas or insulin compared with conventional treatment and risk of complications in patients with type 2 diabetes (UKPDS 33). Lancet 1998, 352:837-853.

47. Kahn SE, Haffner SM, Heise MA, Herman WH, Holman RR, Jones NP, et al: Glycemic durability of rosiglitazone, metformin, or glyburide monotherapy. N Engl J Med 2006, 355:2427-2443.

48. UK Prospective Diabetes Study (UKPDS) Group: Effect of intensive bloodglucose control with metformin on complications in overweight patients with type 2 diabetes (UKPDS 34). Lancet 1998, 352:854-865.

49. Rao AD, Kuhadiya N, Reynolds K, Fonseca VA: Is the combination of sulfonylureas and metformin associated with an increased risk of cardiovascular disease or all-cause mortality?: a meta-analysis of observational studies. Diabetes Care 2008, 31:1672-1678.

50. Deacon CF, Marx N: Potential cardiovascular effects of incretin-based therapies. Expert Rev Cardiovasc Ther 2012, 10:337-351.

51. Chrysant SG, Chrysant GS: Clinical implications of cardiovascular preventing pleiotropic effects of dipeptidyl peptidase-4 inhibitors. Am J Cardiol 2012, 109:1681-1685.

52. Bose AK, Mocanu MM, Carr RD, Brand CL, Yellon DM: Glucagon-like peptide 1 can directly protect the heart against ischemia/reperfusion injury. Diabetes 2005, 54:146-151.

53. Dokken BB, La Bonte LR, Davis-Gorman G, Teachey MK, Seaver N, McDonagh PF: Glucagon-like peptide-1 (GLP-1), immediately prior to reperfusion, decreases neutrophil activation and reduces myocardial infarct size in rodents. Horm Metab Res 2011, 43:300-305.

54. Sauve M, Ban K, Momen MA, Zhou YQ, Henkelman RM, Husain M, et al: Genetic deletion or pharmacological inhibition of dipeptidyl peptidase-4 improves cardiovascular outcomes after myocardial infarction in mice. Diabetes 2010, 59:1063-1073.

55. Ye Y, Keyes KT, Zhang C, Perez-Polo JR, Lin Y, Birnbaum Y: The myocardial infarct size-limiting effect of sitagliptin is PKA-dependent, whereas the protective effect of pioglitazone is partially dependent on PKA Am J Physiol Heart Circ Physiol 2010, 298:H1454-H1465.

56. Basu A, Charkoudian N, Schrage W, Rizza RA, Basu R, Joyner MJ: Beneficial effects of GLP-1 on endothelial function in humans: dampening by glyburide but not by glimepiride. Am J Physiol Endocrinol Metab 2007, 293:E1289-E1295.

57. Nikolaidis LA, Mankad S, Sokos GG, Miske G, Shah A, Elahi D, et al: Effects of glucagon-like peptide- 1 in patients with acute myocardial infarction and left ventricular dysfunction after successful reperfusion. Circulation 2004, 109:962-965.

58. Read PA, Khan FZ, Heck PM, Hoole SP, Dutka DP: DPP-4 inhibition by sitagliptin improves the myocardial response to dobutamine stress and mitigates stunning in a pilot study of patients with coronary artery disease. Circ Cardiovasc Imaging 2010, 3:195-201.

59. Fadini GP, Boscaro E, Albiero M, Menegazzo L, Frison V, de Kreutzenberg S, et al The oral dipeptidyl peptidase-4 inhibitor sitagliptin increases circulating endothelial progenitor cells in patients with type 2 diabetes: possible role of stromal-derived factor-1alpha. Diabetes Care 2010, 33:1607-1609.

60. Takahashi M: Role of the SDF-1/CXCR4 system in myocardial infarction. Circ J 2010, 74:418-423.

61. Zaruba MM, Theiss HD, Vallaster M, Mehl U, Brunner S, David R, et al: Synergy between CD26/DPP-IV inhibition and G-CSF improves cardiac function after acute myocardial infarction. Cell Stem Cell 2009, 4:313-323.
62. Theiss HD, Brenner C, Engelmann MG, Zaruba MM, Huber B, Henschel V, et al: Safety and efficacy of SITAgliptin plus GRanulocyte-colony-stimulating factor in patients suffering from Acute Myocardial Infarction (SITAGRAMI-Trial)-rationale, design and first interim analysis. Int J Cardiol 2010, 145:282-284

63. Hanefeld M, Herman GA, Wu M, Mickel C, Sanchez M, Stein PP: Once-daily sitagliptin, a dipeptidyl peptidase-4 inhibitor, for the treatment of patients with type 2 diabetes. Curr Med Res Opin 2007, 23:1329-1339.

64. Rosenstock J, Brazg R, Andryuk PJ, Lu K, Stein P: Efficacy and safety of the dipeptidyl peptidase-4 inhibitor sitagliptin added to ongoing pioglitazone therapy in patients with type 2 diabetes: a 24-week, multicenter, randomized, double-blind, placebo-controlled, parallelgroup study. Clin Ther 2006, 28:1556-1568.

65. Charbonnel B, Karasik A, Liu J, Wu M, Meininger G: Efficacy and safety of the dipeptidyl peptidase-4 inhibitor sitagliptin added to ongoing metformin therapy in patients with type 2 diabetes inadequately controlled with metformin alone. Diabetes Care 2006, 29:2638-2643.

66. Aschner P, Kipnes MS, Lunceford JK, Sanchez M, Mickel C, Williams-Herman DE: Effect of the dipeptidyl peptidase-4 inhibitor sitagliptin as monotherapy on glycemic control in patients with type 2 diabetes. Diabetes Care 2006, 29:2632-2637.

67. Raz I, Hanefeld M, Xu L, Caria C, Williams-Herman D, Khatami H: Efficacy and safety of the dipeptidyl peptidase-4 inhibitor sitagliptin as monotherapy in patients with type 2 diabetes mellitus. Diabetologia 2006, 49:2564-2571.

68. Hermansen K, Kipnes M, Luo E, Fanurik D, Khatami H, Stein P: Efficacy and safety of the dipeptidyl peptidase- 4 inhibitor, sitagliptin, in patients with type 2 diabetes mellitus inadequately controlled on glimepiride alone or on glimepiride and metformin. Diabetes Obes Metab 2007, 9:733-745.

69. Goldstein BJ, Feinglos MN, Lunceford JK, Johnson J, Williams-Herman DE: Effect of initial combination therapy with sitagliptin, a dipeptidyl peptidase-4 inhibitor, and metformin on glycemic control in patients with type 2 diabetes. Diabetes Care 2007, 30:1979-1987.

70. Williams-Herman D, Johnson J, Teng R, Luo E, Davies MJ, Kaufman KD, et al: Efficacy and safety of initial combination therapy with sitagliptin and metformin in patients with type 2 diabetes: a 54-week study. Curr Med Res Opin 2009, 25:569-583.

71. Williams-Herman D, Johnson J, Teng R, Golm G, Kaufman KD, Goldstein BJ, et al: Efficacy and safety of sitagliptin and metformin as initial combination therapy and as monotherapy over 2 years in patients with type 2 diabetes. Diabetes Obes Metab 2010, 12:442-451.

72. Mohan V, Yang W, Son HY, Xu L, Noble L, Langdon RB, et al: Efficacy and safety of sitagliptin in the treatment of patients with type 2 diabetes in China, India, and Korea. Diabetes Res Clin Pract 2009, 83:106-116.

73. Barzilai N, Guo H, Mahoney EM, Caporossi S, Golm GT, Langdon RB, et al: Efficacy and tolerability of sitagliptin monotherapy in elderly patients with type 2 diabetes: a randomized, double-blind, placebo-controlled trial. Curr Med Res Opin 2011, 27:1049-1058.

74. Aschner $P$, Katzeff $H$, Guo H, Sunga S, Williams-Herman D, Kaufman KD, et al: Efficacy and safety of monotherapy of sitagliptin compared with metformin in patients with type 2 diabetes. Diabetes Obes Metab 2010, 12:252-261

75. Vilsboll T, Rosenstock J, Yki-Jarvinen H, Cefalu WT, Chen Y, Luo E, et al: Efficacy and safety of sitagliptin when added to insulin therapy in patients with type 2 diabetes. Diabetes Obes Metab 2010, 12:167-177.

76. Dobs AS, Goldstein BJ, Aschner P, Horton ES, Umpierrez GE, Duran L, et al: Efficacy and safety of sitagliptin added to ongoing metformin and rosiglitazone combination therapy in a randomized, placebo-controlled 54-week trial in patients with type 2 diabetes. J Diabetes, doi:10.1111/ j.1753-0407.2012.00223.x (Epub ahead of print 28-June-2012).

77. Raz I, Chen Y, Wu M, Hussain S, Kaufman KD, Amatruda JM, et al: Efficacy and safety of sitagliptin added to ongoing metformin therapy in patients with type 2 diabetes. Curr Med Res Opin 2008, 24:537-550.

78. Alba M, Ahren B, Inzucchi SE, Guan Y, Mallick M, Xu L, et al: Sitagliptin and pioglitazone provide complementary effects on postprandial glucose and islet cell function. Diabetes Care 2012, Submitted to Diabetes Care.

79. Yoon KH, Shockey GR, Teng R, Golm GT, Thakkar PR, Meehan AG, et al: Effect of initial combination therapy with sitagliptin, a dipeptidyl peptidase-4 inhibitor, and pioglitazone on glycemic control and measures of beta-cell function in patients with type 2 diabetes. Int J Clin Pract 2011, 65:154-164. 
80. Yoon KH, Steinberg H, Teng R, Golm GT, Lee M, O'Neill EA, et al: Efficacy and safety of initial combination therapy with sitagliptin and pioglitazone in patients with type 2 diabetes: a 54-week study. Diabetes Obes Metab 2012, 14:745-752.

81. Wainstein J, Katz L, Engel SS, Xu L, Golm GT, Hussain S, et al: Initial therapy with the fixed-dose combination of sitagliptin and metformin results in greater improvement in glycaemic control compared with pioglitazone monotherapy in patients with type 2 diabetes. Diabetes Obes Metab 2012, 14:409-418

82. Perez-Monteverde A, Seck T, Xu L, Lee MA, Sisk CM, Williams-Herman DE, et al: Efficacy and safety of sitagliptin and the fixed-dose combination of sitagliptin and metformin vs. pioglitazone in drug-naive patients with type 2 diabetes. Int J Clin Pract 2011, 65:930-938.

83. Yang W, Guan Y, Shentu Y, Li Z, Johnson-Levonas AO, Engel SS, et al: The addition of sitagliptin to ongoing metformin therapy significantly improves glycemic control in Chinese patients with type 2 diabetes. J Diabetes 2012, 4:227-237.

84. Reasner C, Olansky L, Seck TL, Williams-Herman DE, Chen M, Terranella L, et al: The effect of initial therapy with the fixed-dose combination of sitagliptin and metformin compared with metformin monotherapy in patients with type 2 diabetes mellitus. Diabetes Obes Metab 2011, 13:644-652.

85. Olansky L, Reasner C, Seck TL, Williams-Herman DE, Chen M, Terranella L, et al: A treatment strategy implementing combination therapy with sitagliptin and metformin results in superior glycaemic control versus metformin monotherapy due to a low rate of addition of antihyperglycaemic agents. Diabetes Obes Metab 2011, 13:841-849.

86. Henry RR, Staels B, Fonseca VB, Chou MZ, Teng R, Golm GT, Langdon RB, Kaufman KD, Goldstein BJ, Steinberg H: Efficacy and safety of initial combination treatment with sitagliptin and pioglitazone - a factorial study (abstract). 2011 International Diabetes Federation, 21st World Diabetes Congress,

87. Fonseca V, Staels B, Morgan JD, Shentu Y, Golm G, Johnson-Levonas AO, et al: Efficacy and safety of sitagliptin added to ongoing metformin and pioglitazone combination therapy in a randomized, placebo-controlled, 26-week trial in patients with type 2 diabetes. J Diabetes Complicat, . doi pii: S1056-8727(12)00275-9. 10.1016/j.jdiacomp.2012.09.007 (Epub ahead of print 29-October-2012).

88. Scott R, Loeys T, Davies MJ, Engel SS: Efficacy and safety of sitagliptin when added to ongoing metformin therapy in patients with type 2 diabetes. Diabetes Obes Metab 2008, 10:959-969.

doi:10.1186/1475-2840-12-3

Cite this article as: Engel et al:: Cardiovascular safety of sitagliptin in patients with type 2 diabetes mellitus: a pooled analysis. Cardiovascular Diabetology 2013 12:3.

\section{Submit your next manuscript to BioMed Central and take full advantage of:}

- Convenient online submission

- Thorough peer review

- No space constraints or color figure charges

- Immediate publication on acceptance

- Inclusion in PubMed, CAS, Scopus and Google Scholar

- Research which is freely available for redistribution 